\title{
ATP1B3 Gene
}

National Cancer Institute

\section{Source}

National Cancer Institute. ATP1B3 Gene. NCI Thesaurus. Code C132087.

This gene plays a role in ion exchange activity. 